\title{
Differentiated Instruction for Diverse Learners
}

\author{
Marjon C. Malacapay ${ }^{1}$ \\ ${ }^{1}$ Central Philippines State University-Sipalay Campus, Philippines
}

\begin{abstract}
Learners absorb information at their own style which means instruction should be differentiated. Thus, this study was undertaken to structure teacher's teaching instruction based on their pupils' learning styles. Using a self-made survey questionnaire, the researcher determined the learners' demographic profile, academic achievement and learning styles, and further sought significant association towards them. Quantitative in nature and descriptive-correlational by design, the researcher utilized both descriptive and inferential statistics such as percentage distribution, mean and Pearson-product moment correlation to analyze the data. Conducted at Pitgong Elementary School and participated by grade five pupils $(n=30)$ who are partly Indigenous Peoples, mostly male, whose favorite hobby is drawing, and radio is the primary source of information, findings show that auditory learners whose academic achievement is satisfactory dominated the population. Findings further elucidated that there are no significant relationships between demographic profile and learning styles, and between learning styles and academic achievement. Findings also showed that both visual and aural learners learned best when the teacher utilized audio-visual presentations while kinesthetic learners learned best when actual/real objects were applied.
\end{abstract}

Keywords: Basic Education, Differentiated Instruction, Teaching Pedagogy, Philippines

\section{Introduction}

\subsection{Background of the Study}

Two out of three students get bored in their class every single day; 30 percent of them said it was due to lack of interaction while 70 percent was due to non-interesting report materials being taught (Bryner, 2007). Teachers, however, admits that they often struggle to give specific learning activities that work best for them and for all students considering that learners learn in variation (Dixon et al., 2014; Kubat, 2018). This should not supposed to happen, because schools are expected to offer individual-centered education, having a curriculum tailored to a child's intelligence preference (Allan \& Tomlinson, 2000).

In this connection, a model on Differentiated Instruction (DI) is gaining ground in many educational circles (Subban, 2006). In fact, a growing body of research shows positive results for full implementation of DI in mixed-ability classrooms (Rock, Gregg, Ellis, \& Gable, 2008). An example of this was a Canadian three-year study in Alberta. The study found that DI consistently yield positive results (McQuarrie, McRae, \& StackCutler, 2008). Another study made by Tieso (2005) also affirms that DI was effective for keeping high-ability students challenged in heterogeneous classrooms.

Likewise, researchers of the Philippines conducted many studies on DI. Aranda and Zamora's 2016 study concluded that students' academic performance increased after administering DI. Also, in Leonardo et. al. (2015) study in the effects of DI on college students' achievement towards Trigonometry, proved that students exposed in DI have higher academic achievement than those using the traditional lecture method.

This has become a challenge and had made the role of educator complex. This is because their efficacy is an important dimension in differentiation (Tomlison \& Moon, 2014; Dixon et al., 2014). In teaching, LawrenceBrown (2014) suggested using manipulative, visual aids, charts, audiotapes, and explicit expectations in DI. Yet, he did not clarify what instruction fits a specific learning style. Moreover, up to this date, no study made to explore about learners' preferred learning instruction from these suggested instructions to visual, auditory, or kinesthetic. Therefore, this study attempts to bridge this gap. 


\subsection{Theoretical Framework}

The study was anchored in the Theory of Multiple Intelligences. This theory of Gardner (1983) conditions that people do not just have an intellectual capacity, but have many kinds of intelligence, this includes musical, interpersonal, spatial-visual, and linguistic intelligence. This means that learners vary on learning acquisition and teachers must differentiate their instruction. For this reason, the theory is appropriate in this study.

\subsection{Statement of the Problem}

The study sought to answer the following questions:

1. What is grade five learners' demographic profile in terms of a.) sex; b.) ethnicity; c.) access to learning resource; and d.) hobby?

2. What is grade five learners' learning style when taken as a whole and group according to a.) visual; b.) aural; and d.) kinesthetic?

3. What is grade five learners' academic achievement when taken as a whole and group according to a.) visual; b.) auditory; and c.) kinesthetic?

4. What is grade five learners' preferred learning instruction when group according to a.) visual; b.) auditory; and c.) kinesthetic?

5. Is there a significant relationship between grade five learners' demographic profile towards learning styles?

Is there a significant relationship between grade five learners' learning styles towards their academic achievement?

\subsection{Hypotheses}

1. There is no significant relationship between grade five learners' demographic profile towards learning styles.

2. There is no significant relationship between grade five learners' learning styles towards their academic achievement.

\subsection{Scope and Limitation}

The scope of the work presented here is subject to several limitations. First, the study had focused and limit only in three learning styles specifically the visual, auditory, and kinesthetic. Also, only 30 pupils participated in this study due to the small enrollment number of the school. In the distribution of learning style survey questionnaire, $100 \%$ of the pupils participated. But during the real class/session applying the concept of differentiated instruction, some pupils were absent. Therefore, the researcher decided to count only the scores of the learners who were present. This study is further limited on the objectives and topics of 8 subjects (all handled by the researcher) reflected in the curriculum guide of the Department of Education during the second grading period since objectives are non-negotiable. The activities used by the researcher in 4 sessions were also selected by himself based on his readings on the internet, and is considered a limitation.

\section{Materials and Methods}

This quantitative type of research used the descriptive-correlational design as this study first described then investigated the degree of association between each variable. Respondents were Grade $5(n=30)$ learners of Pitgong Elementary School officially enrolled in School Year 2017-2018. This far-flung small school situated on top of the mountain is about 10 kilometers away from the national road and a total of 188 pupils used to study here from kinder to grade 6 and headed by a Teacher-in-charge. Moreover, this study used the purposive sampling specifically the complete enumeration. Hale (2011) stated that this technique used to look at the entire population with a particular set of characteristics. To generate information, this study used a two-part self-made (translated to Hiligaynon dialect) survey questionnaire patterned from different sources available online to profile and figure learners' learning styles, a self-made tally sheet to record their formative scores in four sessions, and form 137 (progress report card) as a basis of their grades. To make sure that the terms used are proper, the questionnaire first underwent a validity test which brought a 4.74 rating interpreted as excellent. Next, the researcher conducted a pilot testing of the questionnaire on randomly selected grade six pupils $(n=15)$ and resulted in a 0.99 coefficient of reliability interpreted as very high. Then. the data gathering took place. First, the 
researcher sought permission, both verbal and through writing, to the School head stating the aim/s of the study and to the parents for parental consent of the respondents. For ethical consideration, a face-to-face orientation of participants highlighting their voluntary involvement took place. Fortunately, everyone participated. Profiling of learners became the starting point of the data gathering procedure. After profiling, the researcher then grouped these learners according to their learning styles. Then, the researcher integrated differentiated instruction in his class. Each session, the researcher applied a different medium of instruction, then conducted a formative test, and tally it in the end. The results were his basis in his conclusion about the learners' preferred instruction. The data gathering took place for almost two months (middle of September to the First week of November) because such instructional materials need more time to prepare. After gathering, consolidating, and encoding of the results, it underwent data analysis using the SPSS application. Tabulating with the statistician's assistance, this study used descriptive and inferential statistics such as the frequency counts, mean, and Pearson-r for data treatment.

\section{Results}

Presented herewith are the results of data treatment and its corresponding analysis.

TABLE I: Demographic Profile Distribution of Grade 5 pupils

\begin{tabular}{lcc}
\hline \hline Demographic Profile & Frequency & Percent \\
\hline Sex & 20 & 67 \\
Male & 10 & 33 \\
Female & 30 & 100 \\
Total & & \\
Ethnicity & 12 & 40 \\
Indigenous Peoples (IP's) & 18 & 60 \\
Non-IP's & 30 & 100 \\
Total & & \\
Access to Learning & 11 & 37 \\
Books & 6 & 20 \\
Cellphone & 1 & 3 \\
Television & 12 & 40 \\
Radio & 0 & 0 \\
Abacus/Counters & 0 & 0 \\
VCD/DVD & 30 & 100 \\
Total & & 3 \\
Hobby & 1 & 17 \\
Reading & 5 & 43 \\
Singing & 13 & 27 \\
Drawing & 8 & 7 \\
Talking & 2 & 0 \\
Listening to Music & 0 & 3 \\
Playing Instrument & 1 & 0 \\
Playing with Friends & 0 & 0 \\
Doing House Chores & 0 & 100 \\
Hiking & 30 & \\
\hline Total & & \\
\hline \hline
\end{tabular}

The demographic profile distribution table above shows that of the thirty (30) grade five learnerrespondents, male learners dominated at 67 percent (20) and only 33 percent (10) are female. The class is also multi-cultural since 60 percent (18) are non-Indigenous Peoples while 40 percent (12) belongs to Indigenous Peoples. While in terms of access to learning, 40 percent (12) have radios, 37 percent (11) have books, 20 percent (6) have cell phones, and 3 percent (1) have television at home. Lastly, 43 percent (13) of the learners 
love to draw $27 \%$ (8) likes talking, 17 percent (5) likes singing, 7 percent (2) likes listening to music, while hobbies such as reading and playing with friends tied with 3 percent (1).

TABLE II: Mean of the Learner's Learning Style

\begin{tabular}{lcc}
\hline \hline Learning Styles & Frequency & Percent \\
\hline Visual & 9 & 30 \\
Auditory & 14 & 47 \\
Kinesthetic & 7 & 23 \\
\hline Total & 30 & 100 \\
\hline \hline
\end{tabular}

The mean of the learner's learning style distribution table above shows that of the thirty (30) grade five learner-respondents, auditory learners dominated. Specifically, when grouped according to learning styles, 47 percent (14) are auditory, 30 percent (9) are visual, and 23\% (7) are kinesthetic learners.

TABLE III: Learner's Academic Achievement

\begin{tabular}{|c|c|c|c|c|c|c|c|}
\hline \multirow[t]{2}{*}{ Grades } & \multicolumn{2}{|c|}{ Visual } & \multicolumn{2}{|c|}{ Auditory } & \multicolumn{2}{|c|}{ Kinesthetic } & \multirow[t]{2}{*}{ Interpretation } \\
\hline & $f$ & $\%$ & $f$ & $\%$ & $\mathrm{f}$ & $\%$ & \\
\hline $90-100$ & 0 & 0 & 1 & 7 & 1 & 13 & Outstanding \\
\hline $85-89$ & 2 & 25 & 3 & 21 & 0 & 0 & Very Satisfactory \\
\hline $80-84$ & 1 & 13 & 8 & 57 & 5 & 63 & Satisfactory \\
\hline $75-79$ & 5 & 63 & 2 & 14 & 2 & 25 & Fairly Satisfactory \\
\hline Below 75 & 0 & 0 & 0 & 0 & 0 & 0 & Did Not Meet Expectation \\
\hline Total & 8 & 100 & 14 & 100 & 8 & 100 & \\
\hline \multirow{2}{*}{ Mean and Interpretation } & 2.67 & & 3.21 & & 3.00 & & \\
\hline & FS & & $\mathrm{S}$ & & $\mathrm{S}$ & & \\
\hline
\end{tabular}

Legend: V-Visual A-Auditory $\quad$ K- Kinesthetic FS- Fairly Satisfactory $S$ - Satisfactory

The learners' academic achievement distribution table above shows that of the thirty (30) grade five learner-respondents, when group according to learning styles, visual learners performed fairly satisfactory (2.67) because 63 percent (5) has a grade between 75-79, 25 percent (2) has 85-89, and 13 percent (1) has 80-84 grade. On the other hand, auditory learners performed satisfactorily (3.21) because 57 percent ( 8 ) has $80-84,32$ percent (3) has 85-89, 14 percent (2) has 75-79, and 7 percent (1) has 90-100 grade. Lastly, kinesthetic learners also performed satisfactorily (3.00) because 63 percent (5) has a grade between 80-84, 25 percent (2) has 75-79, and 3 percent (1) has 90-100 grade. 
TABLE IV: Learners' Preferred Learning Instruction

\begin{tabular}{ll}
\hline \hline Learning Styles with Activities Applied & Percent of Effectiveness \\
\hline Visual Learners & 67 \\
Audio-Visual Presentation & 53 \\
Pictures on Meta-cards & 50 \\
Verbal Teaching only & 30 \\
Graphic Organizers & 26 \\
Plain Text Reading Materials & 25 \\
Realia/Real Objects & \\
Auditory Learners & 82 \\
Audio-Visual Presentation & 81 \\
Verbal Discussion/Teaching & 76 \\
Plain Text Reading Materials & 75 \\
Mnemonics & 67 \\
Picture analysis & 62 \\
Realia & 60 \\
Word Drills & 50 \\
Chorale Reading & 45 \\
Dictation & \\
Kinesthetic Learners & 72 \\
Real Object/Realia & 67 \\
Verbal-finger Memorization & 62 \\
Simulation/ Drama & 50 \\
Chorale Reading & 50 \\
Demonstration by the teacher & 47 \\
Student-teacher interaction & 43 \\
Audio-visual presentation & 43 \\
Jotting down of notes & 19 \\
Games/Play & \\
No class interaction & \\
\hline
\end{tabular}

The table above reveals the percent of effectiveness of each activity/instruction the teacher applied in four sessions to thirty (30) pupils. It revealed that audio-visual presentation (67\%) is the visual learners preferred learning instruction, followed by pictures in meta-cards (53\%), verbal teaching only (50\%), graphic organizers $(30 \%)$, plain text reading materials $(26 \%)$, and with real objects $(25 \%)$. Audio-visual presentation $(82 \%)$ is also the preferred learning instruction by auditory learners, then with verbal discussion/teaching (81\%), plain text reading materials $(76 \%)$, mnemonics $(75 \%)$, picture analysis $(67 \%)$, realia/real objects $(62 \%)$, word drills $(60 \%)$, choral reading $(50 \%)$, and dictation (45\%). Lastly, using of real objects/tactile materials either by the teacher or them $(72 \%)$ after instruction/discussion is the preferred learning instruction of kinesthetic learners, followed by memorizing aloud with the coordination of their fingers (67\%), simulation/drama (62\%), choral reading (50\%), student-teacher interaction (47), jotting down notes while discussing, audio-visual presentation (43\%), games/play (19\%), and learned least if no class interaction (14\%).

TABLE V: Relationship between Learners' Demographic Profile and Learning Style

\begin{tabular}{lcccc}
\hline \hline \multicolumn{1}{c}{ Profile } & Corr. Coef. & p-value & Decision & Interpretation \\
\hline Sex and Learning Style & 0.123 & 0.516 & Accept Ho & Not Significant \\
Ethnicity and Learning Style & 0.11 & 0.562 & Accept Ho & Not Significant \\
Access to Learning and Learning Style & 0.145 & 0.445 & Accept Ho & Not Significant \\
Hobby and Learning Style & 0.15 & 0.43 & Accept Ho & Not Significant \\
\hline \hline
\end{tabular}


The table above reveals the relationship between learners' demographic profile and learning style using Pearson-product moment correlation. Research showed that demographic profile of learners such as sex (Corr. Coef. $=.123, \mathrm{p}$-value $=.156)$, ethnicity $($ Corr. Coef. $=.110, \mathrm{p}$-value $=.562)$, access to learning $($ Corr. Coef. $=.145$, $\mathrm{p}$-value $=.445$ ), and hobby (Corr. Coef. $=.150, \mathrm{p}$-value $=.430$ ) has no significant relationship on learners' learning style. This implies that each one's learning style is independent and is not influence by our demographic profile. It does not rely either on our sex, ethnicity, access to learning, and hobby.

The support of this non-significance result is due to individual difference. Individual learning styles depend on cognitive, emotional, and environmental factors, as well as one's prior experience (Teach.com, 2008).

TABLE VI: Relationship of Learners' Learning Style and Academic Achievement

\begin{tabular}{ccccc}
\hline \hline Variable & Corr. Coef. & p-value & Decision & Interpretation \\
\hline Learning Style and Grades & 1.089 & .403 & Accept Ho & Not Significant \\
\hline \hline
\end{tabular}

The table above reveals the relationship between learners' learning style and academic achievement using Pearson-product moment correlation. From the tabulated results, finding shows that learning style and academic achievement has no significant relationship (Corr. Coef. $=.403, \mathrm{p}$-value $=.403$ ). This implies that learning style has no relevant effect on learners' academic achievement.

The findings obtained was incongruent to the correlational study of Nzesei (2015) among the secondary school students in Kenya. Nzesei (2015) found a strong positive and statistically significant relationship between learning styles and academic achievement for the trimodal learners, and among male and female students.

\section{Discussion}

This study was carried out to determine learners' learning styles, level of academic achievement, and their learning preferences inside a typical classroom. Also, it aimed to explore whether these identified variables affect one another in some ways.

\subsection{Summary of Findings}

Following are the research findings made out from the results gathered from 30 grade five learners dominated by male, multi-cultural, radio listeners, and are passionate to draw. Findings show that auditory learners having satisfactory academic achievement dominated the classroom. Also, it reveals that these set of learners have their preferred learning styles more specifically visual and auditory learners preferred learning with the aid of Audio-Visual Presentation while kinesthetic learners learned best with the aid of real objects/realia. Furthermore, findings show no significant relationship between demographic profile and learning style, as well as between learning style and academic achievement.

\subsection{Conclusion}

Given these findings, in conclusion, learning style does not confine itself in one specific demographic profile. Meaning, born as male does not guarantee all men to become visual learners, nor being born as an indigenous people makes them destined to become auditory. Also, it could be concluded that no specific learning style can guarantee high academic achievement. Being a visual learner cannot guarantee high grades and being a kinesthetic learner is not a reason to blame anyone's academic failure.

\subsection{Recommendations}

Here are the recommendations and suggestions made based on the facts and findings. Parents and teachers may give wide-ranging activities that may stimulate the interests of all types of learners. They may also use a variety of instructions and materials as their children's learning acquisition varies. It is also suggested to refrain on giving of specific standards for children to follow and how they should learn, rather give them the freedom to explore according to their preferences. Teachers may also give a variety of selections, especially on performance assessment for equal opportunity to learners. Teachers as well as suggested to update themselves about the proper use and integration of AVP during classes. Teachers may also use a real/replica of objects or any tactile things when teaching. Lastly, the Department of Education may invest and produce more content-based educational videos (preferably in the Filipino language) and make it available online. 


\section{Acknowledgments}

First, the author acknowledges the Father Almighty as the source of his wisdom Also, he extends his heartfelt acknowledgment to several people and institutions for their benevolence. To the Department of Education (DepEd) for funding this attempt under the Basic Education Research Fund (BERF). To Central Philippines State University (CPSU) through its president Dr. Aladino C. Moraca, Dr. Joel A. Perez, VP for Research and Extension, Dr. Mae Flor G. Posadas, Director for Research and Development Services, and Engr. Marc Alexei Caesar B. Badajos, campus administrator of CPSU Sipalay for funding this presentation. To the Schools Division Office of Kabankalan City through the OIC, SDS Anthony H. Liobet, CESO VI, and the Division Research Committee Dr. Saturnino Pabalinas, Jr., secretariat, and SEPS for Research and Planning Rene S. Erillo for their guidance and help. Lastly, an acknowledgment to his parents Jocelyn and Maximiano, and brother Cedric for the inspiration.

\section{References}

[1] Allan, S.D. \& Tomlinson, C.A. (2000). Leadership for differentiating schools and classrooms. Alexandria VA: ASCD.

[2] Aranda, M R \& Zamora, J. (2016). Using Differentiated Instruction in Improving the Academic Performance of Students in the Filipino Language. Retrieved from https://www.national-u.edu.ph/wp-content/uploads/2016/08/JSTAR4_Aranda.pdf

[3] Baykan Z., Naçar M. (2007). Learning styles of first-year medical students attending Erciyes University in Kayseri, Turkey. Adv Physiol Educ 31: 158-160.

[4] Bryner, J. (2007). Most Students Bored at School. Retrieved from https://www.livescience.com/1308-students-boredschool.html

[5] Dixon, F. A., Yssel, N., McConnell, J. M., \& Hardin, T. (2014). Differentiated instruction, professional development, and teacher efficacy. Journal for the Education of the Gifted, 37(2), 111-127. https://doi.org/10.1177/0162353214529042

[6] Gardner, H. (1983). Frames of Mind: The Theory of Multiple Intelligences. New York: Basic Books. Cited by Cherry, K. (2018). Gardner's Theory of Multiple Intelligences. Retrieved from https://www.verywellmind.com/gardners-theoryof-multiple-intelligences-2795161

[7] Hale, J. (2011). The 3 Basic Types of Descriptive Research Methods. Psych Central. Retrieved from https://psychcentral.com/blog/the-3-basic-types-of-descriptive-research-methods/

[8] Kubat, Ulas. (2018). Identifying the Individual Differences Among Students During Learning and Teaching Process by Science Teachers. International Journal of Research in Education and Science. 30-68. 10.21890/ijres.369746.

[9] Leonardo, R., et. al., (2015). Effects of differentiated learning on college students' achievement in and attitude towards trigonometry.

[10] Lawrence-Brown, D. (2004). Differentiated instruction: Inclusive strategies for standards-based learning that benefit the whole class. American Secondary Education 32(3), 34.

[11] McQuarrie, L., McRae, P., \& Stack-Cutler, H. (2008). Differentiated instruction provincial research review. Edmonton: Alberta Initiative for School Improvement.

[12] Nzeseia, M.M. (2015). Correlation Study Between Learning Styles and Academic Achievement Among Secondary School Students in $\quad$ Kenya. Retrieved from http://erepository.uonbi.ac.ke/bitstream/handle/11295/93142/Mutua_A+correlation+study+between+learning+styles+a nd+academic+achievement+among+secondary+school.pdf?sequence $=1$

[13] Rock, M., Gregg, M., Ellis, E., \& Gable, R. A. (2008). REACH: A framework for differentiating classroom instruction. Preventing School Failure, 52(2), 31-47.

[14]Teach.com. (2008). Learning Styles All Students Are Created Equally (and Differently). Retrieved from https://teach.com/what/teachers-know/learning-styles/

[15] Tieso, C. (2005). The effects of grouping practices and curricular adjustments on achievement. Journal for the Education of the Gifted, 29(1), 60-89.

[16] Subban, P. (2006). Differentiated instruction: A research basis. International Education Journal, 7(7), 935-947. https://doi.org/10.1111/j.1365-2648.2006.04074.x 